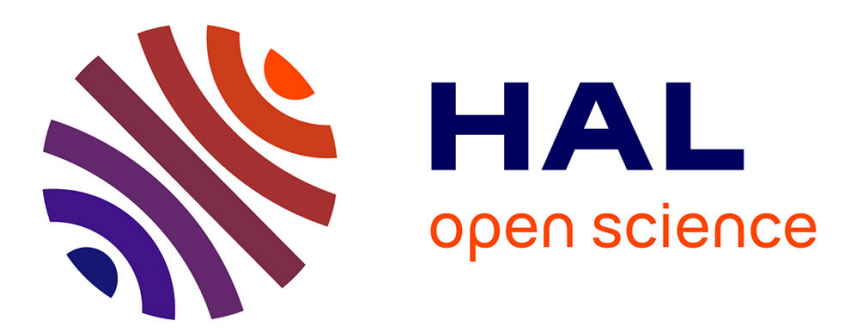

\title{
In the aftermath of Permian-Triassic boundary mass-extinction: new ostracod (Crustacea) genus and species from South Tibet
}

\author{
Marie-Béatrice Forel, S. Crasquin
}

\section{- To cite this version:}

Marie-Béatrice Forel, S. Crasquin. In the aftermath of Permian-Triassic boundary mass-extinction: new ostracod (Crustacea) genus and species from South Tibet. Geodiversitas, 2011, 33 (2), pp.247-263. 10.5252/g2011n2a3 . mnhn-02326941

\section{HAL Id: mnhn-02326941}

\section{https://hal-mnhn.archives-ouvertes.fr/mnhn-02326941}

Submitted on 11 Dec 2020

HAL is a multi-disciplinary open access archive for the deposit and dissemination of scientific research documents, whether they are published or not. The documents may come from teaching and research institutions in France or abroad, or from public or private research centers.
L'archive ouverte pluridisciplinaire HAL, est destinée au dépôt et à la diffusion de documents scientifiques de niveau recherche, publiés ou non, émanant des établissements d'enseignement et de recherche français ou étrangers, des laboratoires publics ou privés. 


\title{
In the aftermath of Permian-Triassic boundary mass-extinction: new ostracod (Crustacea) genus and species from South Tibet
}

\author{
Marie-Béatrice FOREL \\ Sylvie CRASQUIN \\ UPMC Université Paris 06, CNRS, UMR 7207 CR2P, \\ Laboratoire de Micropaléontologie, T.46-56, E.5, \\ case 104, F-75252 Paris cedex 05 (France) \\ marie-beatrice.forel@upmc.fr \\ sylvie.crasquin@upmc.fr
}

KEY WORDS

Crustacea, Ostracods, Lower-Middle Triassic, South Tibet, new genus, new species.

MOTS CLÉS

Crustacea,

Ostracodes,

Trias inférieur et moyen, sud Tibet,

genre nouveau, espèces nouvelles.
Forel M.-B. \& Crasquin S. 2011. - In the aftermath of Permian-Triassic boundary massextinction: new ostracod (Crustacea) genus and species from South Tibet. Geodiversitas 33 (2): 247-263. DOI: $10.5252 / g 2011 \mathrm{n} 2 \mathrm{a} 3$.

\section{ABSTRACT}

46 samples were processed for a taxonomic ostracod study from the LowerMiddle Triassic (Smithian to Anisian) of South Tibet. Forty four species belonging to 15 genera are recognized. One genus and seven species are described as new: Bairdia jeancharlesi Forel n. sp., Bairdia letangae Forel n. sp., Bairdiacypris combeae Forel n. sp., Petasobairdia collini Forel n. sp., Hungarella tulongensis Crasquin n. sp., Triassicindivisia tibetinella Crasquin n. gen., n. sp., Liuzhinia larmae Forel n. sp. The goal of this paper is to describe the new taxa as a preliminary step to palaeoenvironmental reconstruction.

\section{RÉSUMÉ}

Après l'extinction en masse de la limite Permien-Trias: nouveau genre et nouvelles espèces d'ostracodes du sud Tibet.

Quarante-six échantillons ont été analysés pour l'étude des ostracodes du Trias inférieur et moyen (Smithien à Anisien) du sud Tibet. Quarante-quatre espèces appartenant à 15 genres ont été identifiées. Un genre et sept espèces sont nouveaux: Bairdia jeancharlesi Forel n. sp., Bairdia letangae Forel n. sp., Bairdiacypris combeae Forel n. sp., Petasobairdia collini Forel n. sp., Hungarella tulongensis Crasquin n. sp., Triassicindivisia tibetinella n. gen. n. sp., Liuzhinia larmae Forel n. sp. Le sujet de cet article est la description des nouveaux taxons en prélude à une reconstruction paléoenvironnementale. 


\section{INTRODUCTION}

\section{GEOLOGICAL SETTING}

The Tulong section was located on the North Indian margin during the Early Triassic. It crops out near the village of Tulong $\left(28^{\circ} 26^{\prime} 13^{\prime \prime} \mathrm{N}\right.$, $86^{\circ} 08^{\prime} 09^{\prime \prime} \mathrm{E} ; 4430 \mathrm{~m}$ ) on the road from Lhasa to Nyalam (Fig. 1). This section is well known for its Lower Triassic succession in South Tibet. It was described by Garzanti et al. (1998) and more recently by Shen et al. (2006). More recently, the Permian-Triassic interval in this area was restudied by a team from Zurich (Switzerland) and the stratigraphic succession obtained from other outcrops allow establishment of an almost complete succession from the Upper Permian up to the Lower Anisian (Brühwiler et al. 2009). The Tulong section corresponds to units III to VI of the Tulong Formation and is very well dated by ammonoids and conodonts (Brühwiler et al. 2009). It is beyond the scope of this paper to re-describe the section in detail. The following short presentation of the section (Fig. 2) is based on Brühwiler et al. (2009).

The unit III corresponds to $9 \mathrm{~m}$ of mostly grey limestone beds alternating with thin shale intervals. It is subdivided in four sub-units. The sub-unit IIIa is composed of $1.60 \mathrm{~m}$ of red-weathering dolomitized calcarenite and grey packstones and is Smithian in age (based on conodonts); this subunit was not sampled. The sub-unit IIIb consists of $20 \mathrm{~m}$ of thin-bedded, platy to nodular, grey to light red limestones alternating with shale interbeds and is Middle Smithian in age (conodonts). The sub-unit IIIc is $4 \mathrm{~m}$ thick and is composed of medium bedded grey limestone alternating with shales or very nodular marly limestone. The lower part of sub-unit IIIc contains middle Smithian ammonoids and the upper part late Smithian ammonoids. The sub-unit IIId consists of $1 \mathrm{~m}$ of massive very nodular marly limestone of latest Smithian age (ammonoids and conodonts).

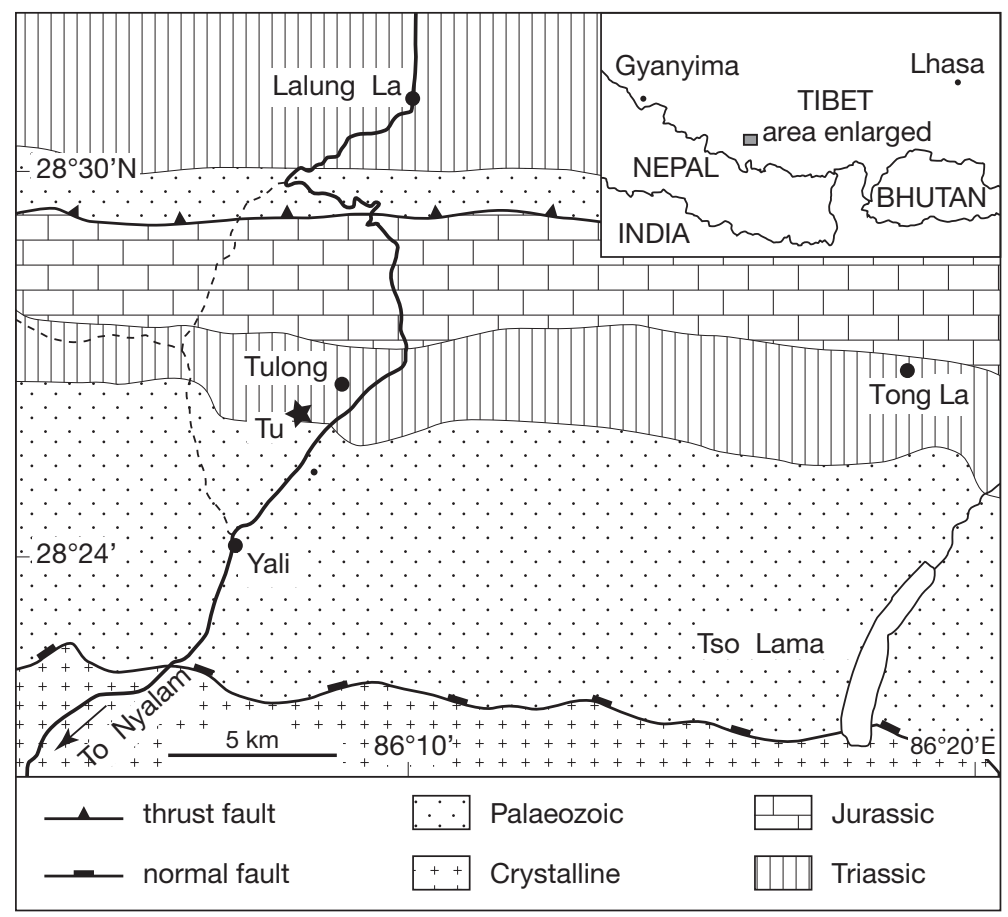

FIG. 1. - Location map of the Tulong section ( $\star$ ), South Tibet (after Brühwiler et al. 2009). 


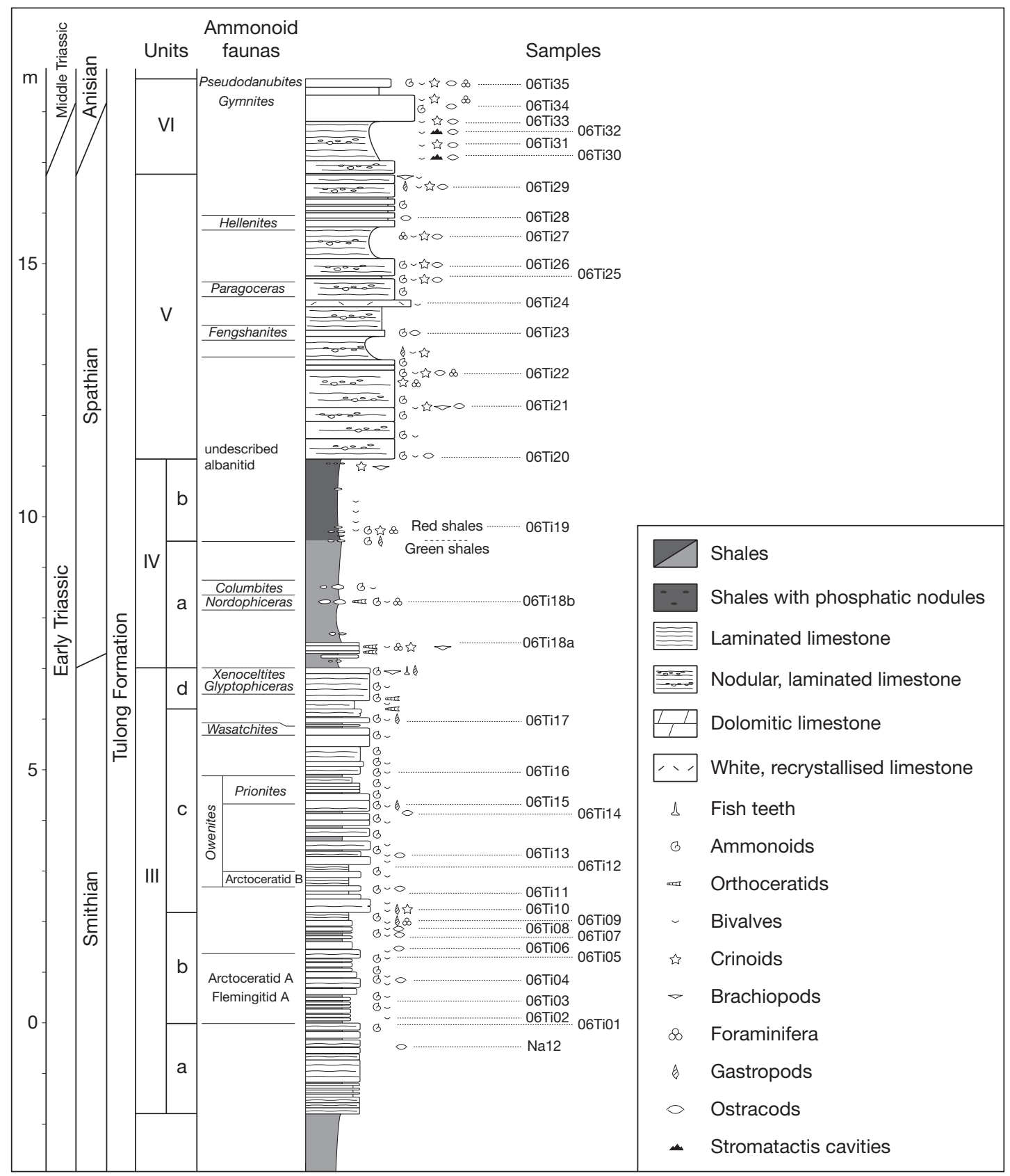

FIG. 2. - Log of the Tulong section, South Tibet, with the location of the studied samples (after Brühwiler et al. 2009).

The unit IV corresponds to $4 \mathrm{~m}$ of shales of early Spathian age (conodonts and ammonoids) subdivided into a lower green part and an upper red part.
The unit $\mathrm{V}$ is $6 \mathrm{~m}$ thick and consist of nodular, marly and bioturbated limestones of "ammonitico rosso" facies (Garzanti et al. 1998) 
and is middle Spathian in age (ammonoids and conodonts).

The last unit, unit VI, consists of $1 \mathrm{~m}$ of thinbedded yellowish nodular limestones overlain by less than $1 \mathrm{~m}$ of grey and yellowish limestone. The last beds contain early middle Anisian ammonoids.

\section{MATERIAL AND METHOD}

Forty six samples, distributed through a $21 \mathrm{~m}$ thick sequence (Fig. 2), were processed by hot acetolysis method (Lethiers \& Crasquin-Soleau 1988; Crasquin-Soleau et al. 2005) which allows the extraction of calcareous shells contained in calcareous rocks. Twenty-nine samples gave ostracods; three of them yielded only indeterminable specimens.

Except for several specimens, in most of cases, the preservation of ostracods is poor and the number of specimens is low. Internal features were not observed.

Forty four species belonging to 15 genera are identified and figured (Figs 3-8). Seven species and one genus are new and described in detail in this paper. Other indicative species are also figured (Figs 3-8) and a complete list is available in Table 1.

All the specimens are deposited in the Université Pierre et Marie Curie, Paris (UPMC) collection (numbers: P6Mxx).

$\begin{array}{ll}\text { ABBREVIATIONS } \\ \text { AB } & \text { anterior border; } \\ \text { ADB } & \text { antero-dorsal border; } \\ \text { AVB } & \text { antero-ventral border; } \\ \text { DB } & \text { dorsal border; } \\ \text { H } & \text { height; } \\ \text { L } & \text { length; } \\ \text { LV } & \text { left valve; } \\ \text { PB } & \text { posterior border; } \\ \text { PDB } & \text { postero-dorsal border; } \\ \text { PVB } & \text { postero-ventral border; } \\ \text { RV } & \text { right valve; } \\ \text { VB } & \text { ventral border; } \\ \text { W } & \text { width. }\end{array}$

\section{SYSTEMATIC PALAEONTOLOGY}

Class OSTRACODA Latreille, 1806

Subclass PODOCOPA Müller, 1894

Order PODOCOPIDA Müller, 1894

Suborder PODOCOPINA Sars, 1866

Superfamily BAIRDIOIDEA Sars, 1887

Family BAIRDIIDAE Sars, 1887

Genus Bairdia McCoy, 1844

Type SPECIES. — Bairdia curta McCoy, 1844.

Bairdia jeancharlesi Forel n. sp.

(Fig. 3I-L)

TYPE MATERIAL. - Holotype: one complete carapace (P6M2607; Fig. 3J); paratype: one complete carapace (P6M2603; Fig. 3I).

Eтymology. - Dedicated to Jean-Charles Forel, personal dedication.

Material eXAmined. - 26 complete carapaces and 1 single valve.

Dimensions. $-\mathrm{L}=435$ to $1120 \mu \mathrm{m} ; \mathrm{H}=260$ to $680 \mu \mathrm{m}$. Holotype: $\mathrm{L}=453 \mu \mathrm{m} ; \mathrm{H}=276 \mu \mathrm{m}$. Paratype: $\mathrm{L}=895 \mu \mathrm{m} ; \mathrm{H}=535 \mu \mathrm{m}$.

TyPe Horizon. - Sample 06Ti08, unit IIIb, Tulong Formation, Smithian, Lower Triassic.

TyPe LOCALity. - Tulong section, Southern Tibet.

OCCURRENCE. - Tulong section, southern Tibet. Samples 06Ti04, 06Ti08, 06Ti21, 06Ti27-31, 06Ti35, Tulong Formation, units III, V and VI, Smithian to Anisian, Lower-Middle Triassic.

Diagnosis. - A punctate species of Bairdia with faint overlap, $\mathrm{AB}$ and $\mathrm{PB}$ with quite small radius of curvature, $\mathrm{PDB}, \mathrm{BD}$ and $\mathrm{ADB}$ straight at RV.

\section{DESCRIPTION}

$\mathrm{RV}$ : $\mathrm{PDB}, \mathrm{DB}$ and $\mathrm{ADB}$ straight; $\mathrm{AB}$ regularly arched with maximum of curvature located in its middle; AVB and PVB regularly convex; VB concave

FIG. 3. - Specimens from Tulong section (Tibet), stored at the Pierre et Marie Curie University Collections (Paris, France): A-E, Bairdia letangae Forel n. sp.; A, holotype (P6M2595), right lateral view of a complete carapace; B, paratype (P6M2596), right lateral view; C, right lateral view of a broken carapace (P6M2597); D, right lateral view of a broken carapace (P6M2598); E, left lateral view of a 


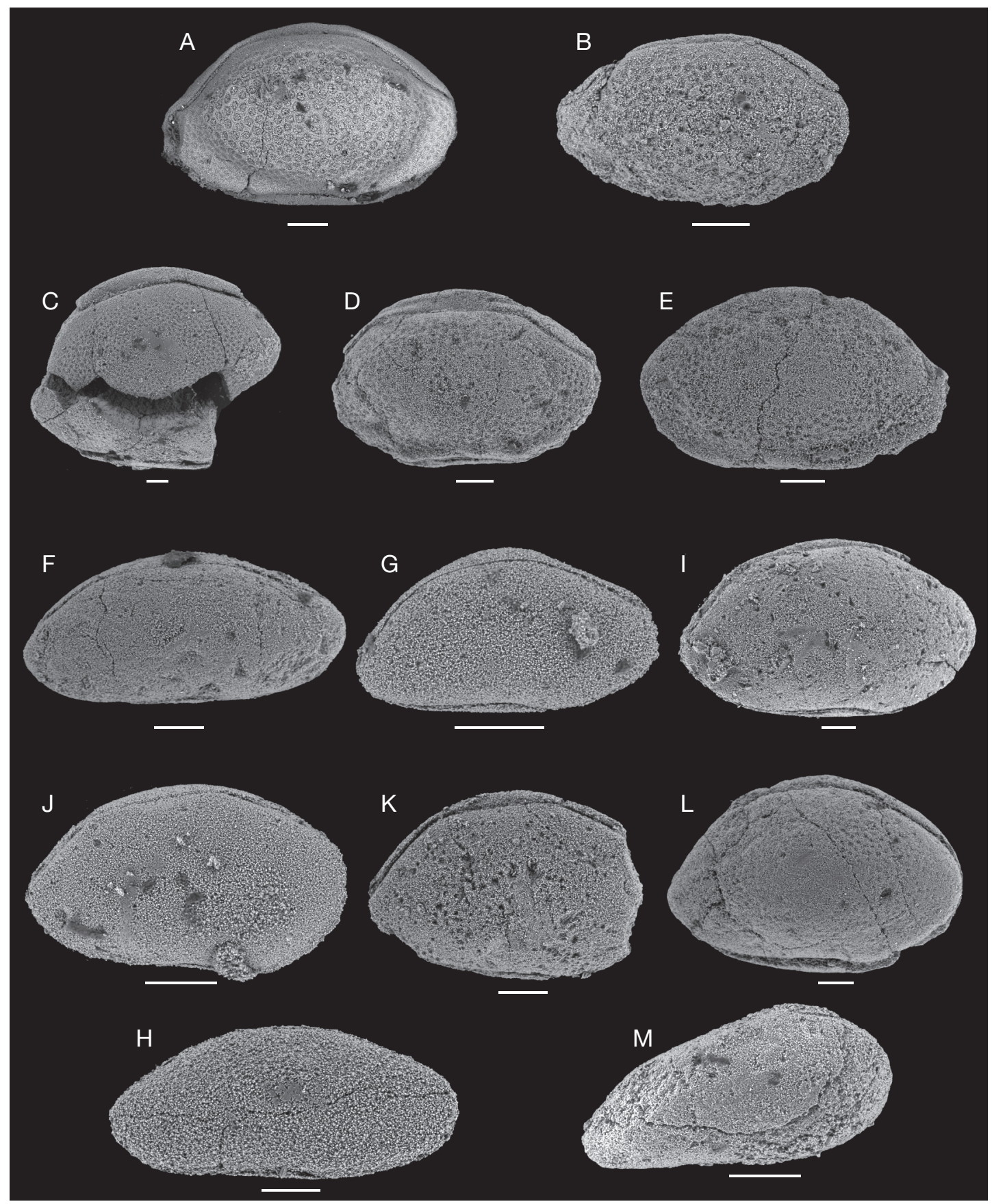

complete carapace (P6M2599); F-H, Bairdia finalyi (Méhes, 1911); F, right lateral view of a complete carapace (P6M2601); G, right lateral view of a complete carapace (P6M2602); H, right lateral view of a complete carapace (P6M2606); I-L, Bairdia jeancharlesi Forel n. sp. ; I, paratype (P6M2603), right lateral view of a complete carapace; J, holotype (P6M2607), right lateral view of a complete carapace; K, right lateral view of a broken carapace (P6M2604); L, right lateral view of a complete carapace (P6M2605); M, Spinocypris vulgaris Kozur, 1971, right lateral view of a complete carapace (P6M2600). Scale bars: $100 \mu \mathrm{m}$. 
TABLE 1. - Distribution chart and abundances of Lower and Middle Triassic ostracods in the Tulong section. The global extension of each species within the section is represented with grey parts. Abundances are indicated as follows: $\bullet$, between 1 and 5 specimens; $\square$, between 5 and 10 specimens; $\bullet$, between 10 and 20 specimens; $\mathbf{x}$, more than 20 specimens.

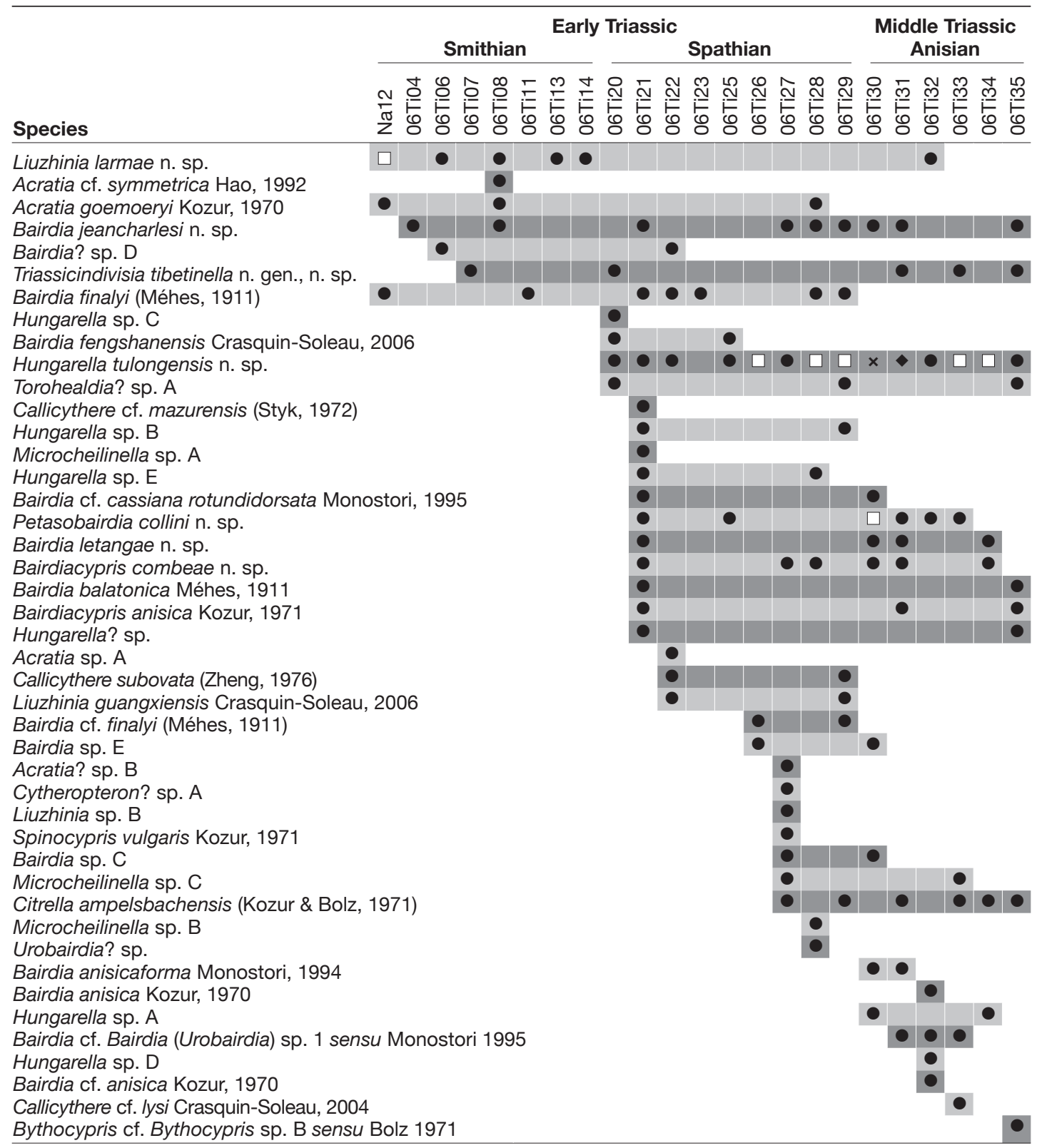

in its anterior part; $\mathrm{PB}$ with quite small radius of curvature but bairdoid beak poorly expressed. LV: PDB straight, DB regularly arched, ADB straight to gently arched, $\mathrm{AB}$ rounded with maximum of curvature in its middle; AVB, VB and PVB arched; $\mathrm{PB}$ with quite small radius of curvature. Carapace 
ornamented by small punctations, flattened laterally in posterior and anterior parts; overlap is small with maximum in anterior part of $\mathrm{DB} ; \mathrm{H} / \mathrm{L}=0.61$.

\section{REMARKS}

Bairdia jeancharlesi Forel n. sp. is close to Bairdia cassiana rotundidorsata Monostori, 1995 from the Anisian of Balaton area (Hungary; Monostori 1995). Here, the carapace is shorter, the overlap is weaker and the DB and PDB are more inclined posteriorly.

\section{Bairdia letangae Forel n. sp.}

(Fig. 3A-E)

TYPe MATERial. - Holotype: one complete carapace (P6M2596; Fig. 3A); paratype: one complete carapace (P6M2595; Fig. 3B).

Etymology. - Dedicated to Béatrice Letang, personal dedication.

MATERIAL EXAMINED. -7 complete carapaces and 2 single valves.

Dimensions. $-\mathrm{L}=540-785 \mu \mathrm{m} ; \mathrm{H}=320-500 \mu \mathrm{m}$. Holotype: $\mathrm{L}=785 \mu \mathrm{m} ; \mathrm{H}=492 \mu \mathrm{m}$. Paratype: $\mathrm{L}=$ $540 \mu \mathrm{m} ; \mathrm{H}=320 \mu \mathrm{m}$.

Type Horizon. - Sample 06Ti30, unit VI, Tulong Formation, Early Anisian, Middle Triassic.

Type Locality. - Tulong section, Southern Tibet.

OCCURRENCE. - Tulong section, Southern Tibet. Samples 06Ti21, 06Ti30, 06Ti31 and 06Ti34, Tulong Formation, units V and VI, Spathian-Anisian, Early-Middle Triassic.

Diagnosis. A massive species of ornamented Bairdia with $\mathrm{AB}$ and $\mathrm{PB}$ flattened, large reticulation on all the carapace except the dorsal margin.

\section{DESCRIPTION}

At RV, PDB straight, $\mathrm{DB}$ long and more or less horizontal, $\mathrm{ADB}$ straight to gently concave. At LV all dorsal parts form a regular arch. $A B$ with quite small radius of curvature; $\mathrm{AVB}$ and $\mathrm{PDB}$ regularly arched; VB straight at LV, gently concave RV; PB with medium radius of curvature; maximum of curvature of $\mathrm{PB}$ and $\mathrm{AB}$ located at the same $\mathrm{H}$; carapace strongly compressed along free margins and particularly in $\mathrm{AB}$ and $\mathrm{PB}$; surface ornamented by a large reticula- tion, this reticulation is present on all the surface except for dorsal margins of both valves.

\section{REMARKS}

Bairdia letangae Forel n. sp. is similar to Bairdia ortiseiensis Crasquin, 2008 from the Late Permian of the Tesero section (Northern Italy; Crasquin et al. 2008). Here the DB is longer, the radius of curvature of $\mathrm{AB}$ is more important and the overlap is stronger. Compared to Lobobairdia zapfei Kozur, 1971 from the Anisian of Balaton area (Kozur 1971; Monostori 1995), Bairdia letangae Forel n. sp. has a straighter $\mathrm{DB}$ and reticulation present all over the carapace surface.

\section{Genus Petasobairdia Chen, 1982}

TyPe SPECIES. - Petasobairdia bicornuta Chen, 1982 (in Chen \& Shi 1982).

Petasobairdia collini Forel n. sp. (Fig. 4I-M)

TYPE MATERIAL. - Holotype: one complete carapace (P6M2615; Fig. 4M); paratype: one complete carapace (P6M2619; Fig. 4J).

Etymology. - Dedicated to Dr Pierre-Yves Collin, Université Pierre et Marie Curie, Paris.

MATERIAL EXAMINED. - 18 complete carapaces and 20 isolated valves.

Dimensions. $-\mathrm{L}=630-1140 \mu \mathrm{m} ; \mathrm{H}=350-700 \mu \mathrm{m}$. Holotype: $\mathrm{L}=1030 \mu \mathrm{m} ; \mathrm{H}=680 \mu \mathrm{m}$. Paratype: $\mathrm{L}=$ $848 \mu \mathrm{m} ; \mathrm{H}=546 \mu \mathrm{m}$.

Type Horizon. - Sample 06Ti30, unit VI, Tulong Formation, Early Anisian, Middle Triassic.

Type LOCALITY. - Tulong section, Southern Tibet.

OCCURRENCE. - Tulong section, Southern Tibet. Samples 06Ti21, 06Ti25, 06Ti30, 06Ti32, 06Ti33, Tulong Formation, units V and VI, Spathian-Anisian, EarlyMiddle Triassic.

Diagnosis. - A species of Petasobairdia with slight dorsal blade at LV, PB with very small radius of curvature and fingerprint ornamentation of fine ribs. 


\section{DESCRIPTION}

RV: PDB, DB and ADB straight; DB quite horizontal compared with $\mathrm{VB}$; $\mathrm{AB}$ with medium radius of curvature, maximum of curvature at mid-H; VB nearly straight to gently concave; $\mathrm{PB}$ with very small radius of curvature and maximum of curvature located at mid $\mathrm{H}$;

LV: dorsal and ventral parts regularly arched; DB being more or less one third of length; presence of a dorsal blade.

Carapace laterally compressed at AB, AVB, PVB and PB; LV overlaps RV on dorsal and ventral margins with maximum on DB; carapace ornamented by a very fine reticulation organized in fingerprint of fine ribs parallel to margins.

\section{REMARKS}

Petasobairdia collini Forel n. sp. is close to two Late Permian species from South China. Petasobairdia nantongensis Chen, 1982 (in Chen \& Shi 1982) has a shorter $\mathrm{VB}$, overlap less important on $\mathrm{ADB}$ and $\mathrm{PDB}$, $\mathrm{AB}$ and $\mathrm{PB}$ are smaller. Petasobairdia subnantongensis Chen, 1987 (in Shi \& Chen 1987) has a longer DB particularly on LV and has a ventral "blade".

Genus Bairdiacypris Bradfield, 1935

TYPe SPECIES. — Bairdiacypris deloi Bradfield, 1935.

Bairdiacypris combeae Forel n. sp.

(Fig. 5F-H)

Fabalicypris reniformis. - Hao 1992: 41, 42, pl. 1, figs 10, 11.

TYPE MATERIAL. - Holotype: one complete carapace (P6M2624; Fig. 5F); paratype: one complete carapace (P6M2625; Fig. 5H).

Etymology. - Dedicated to Simone Combe, personal dedication.

MATERIAL EXAMINED. -9 complete carapaces.
Dimensions. $-\mathrm{L}=495-770 \mu \mathrm{m} ; \mathrm{H}=245-375 \mu \mathrm{m}$. Holotype: $\mathrm{L}=529 \mu \mathrm{m} ; \mathrm{H}=245 \mu \mathrm{m}$. Paratype: $\mathrm{L}=$ $754 \mu \mathrm{m} ; \mathrm{H}=360 \mu \mathrm{m}$.

Type Horizon. - Sample 06Ti30, Unit VI, Tulong Formation, Anisian, Middle Triassic.

TyPe LOCALITY. - Tulong section, Southern Tibet.

OCCURRENCE. - Tulong section, Southern Tibet. Samples 06Ti21, 06Ti27, 06Ti28, 06Ti30 and 06Ti34, units V and VI, Spathian-Anisian, Early-Middle Triassic.

DiaGNOSIS. - A species of Bairdiacypris with maximum of height located in posterior part of the carapace, $A B$ with small radius of curvature and maximum of curvature located high.

\section{DESCRIPTION}

$\mathrm{DB}$ short and straight at both valves; $\mathrm{ADB}$ long and straight; $A B$ with quite small radius of curvature with maximum convexity located high (just below mid-H); VB long, convex at LV and concave at $\mathrm{RV}$; PB with small radius of curvature with maximum of convexity located low (below lower $1 / 3$ of $\mathrm{H})$; carapace long $(\mathrm{H} / \mathrm{L}=0.46)$; maximum of $\mathrm{H}$ located in posterior third of $\mathrm{L}$.

\section{REMARKS}

Bairdiacypris combeae Forel n. sp. is close to Bairdiacypris reniformis (Chen, 1958) from the Early Permian of South China. In B. combeae Forel n. sp. the radius of curvature of $\mathrm{AB}$ and $\mathrm{PB}$ are smaller.

\section{Genus Liuzhinia Zheng, 1976}

TyPe SPECIES. — Liuzhinia subovata Zheng, 1976.

\section{Liuzhinia larmae Forel n. sp. (Fig. 6C-G)}

TYPe MATERIAL. - Holotype: one complete carapace (P6M2638; Fig. 6C); paratype: one complete carapace (P6M2639; Fig. 6D).

FIG. 4. - Specimens from Tulong section (Tibet), stored at the Pierre et Marie Curie University Collections (Paris, France): A, Bairdia fengshanensis Crasquin-Soleau, 2006, right lateral view of a complete carapace (P6M2608); B, Bairdia sp. C, right lateral view of a complete carapace (P6M2609); C, Acratia? sp. B, right lateral view of a complete carapace (P6M2610); D, Bairdia anisicaforma Monostori, 1994, right lateral view of a complete carapace (P6M2611); E, Bairdia sp. F, right lateral view of a complete carapace (P6M2612); 


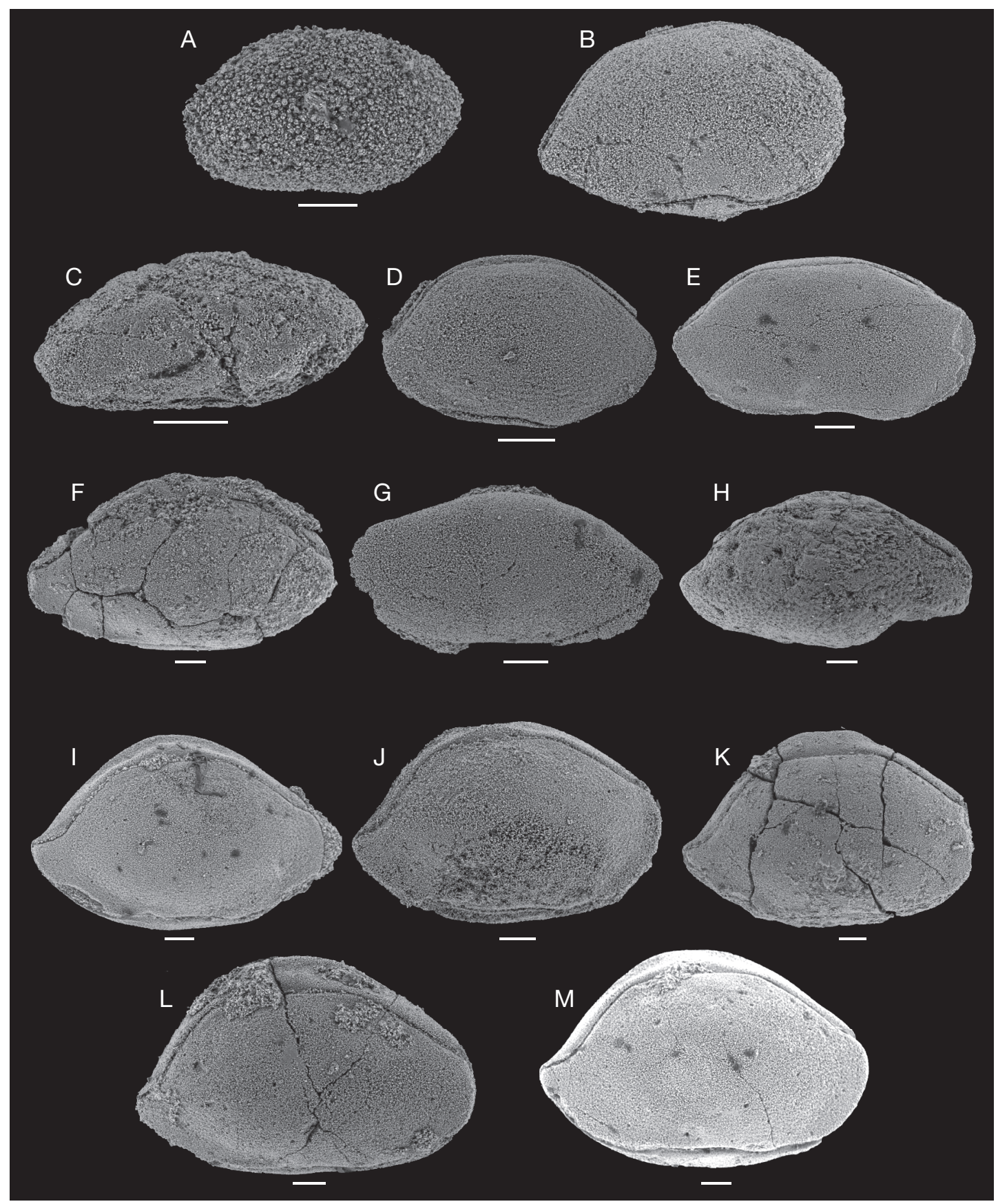

F, Bairdia anisica Kozur, 1970, right lateral view of a complete carapace (P6M2613); G, Bairdia? sp. D, left lateral view of a complete carapace (P6M2614); H, Bairdia cf. finalyi (Méhes, 1911), right lateral view of a broken carapace (P6M2620); I-M, Petasobairdia collini Forel n. sp.; I, right lateral view of a complete carapace (P6M2617); J, paratype (P6M2619), right lateral view of a nearly complete carapace (dorsal part of left valve is missing); K, right lateral view of a nearly complete carapace (P6M2613); L, right lateral view of a complete carapace (P6M2618); M, holotype (P6M2615), right lateral view of a complete carapace. Scale bars: $100 \mu \mathrm{m}$. 
Etymology. - Dedicated to Kriemhilde Larm, personal dedication.

MATERIAL EXAMINED. - 32 complete carapaces and 1 isolated valve.

Dimensions. $-\mathrm{L}=350-570 \mu \mathrm{m} ; \mathrm{H}=175-290 \mu \mathrm{m}$. Holotype: $\mathrm{L}=406 \mu \mathrm{m} ; \mathrm{H}=200 \mu \mathrm{m}$. Paratype: $\mathrm{L}=$ $388 \mu \mathrm{m} ; \mathrm{H}=206 \mu \mathrm{m}$.

TyPe HORIZON. - Sample 06Ti08, Unit IIIb, Tulong Formation, Smithian, Lower Triassic.

Type LOCAlity. - Tulong section, Southern Tibet.

OCCURRENCE. - Tulong section, Southern Tibet. Samples 06Ti06, 06Ti08, 06Ti13, 06Ti14 and 06Ti32, units III to VI, Smithian-Anisian, Early-Middle Triassic.

DiAGNOSIs. - A Liuzhinia species with long and straight dorsal border; $\mathrm{AB}$ and $\mathrm{PB}$ with small radius of curvature.

\section{DESCRIPTION}

$\mathrm{DB}$ long and straight; $\mathrm{AB}$ with relatively small radius of curvature; $\mathrm{VB}$ long and gently convex on both valves; $\mathrm{PB}$ with small radius of curvature; $\mathrm{AB}$ and PB gently compressed laterally at the extremities of the carapace; maximum of $\mathrm{H}$ located in front of $\mathrm{L}$ anterior third; $\mathrm{H} / \mathrm{L}=0.51$

\section{REMARKS}

Liuzhinia larmae Forel n. sp. is very close from Liuzhinia antalyaensis Crasquin-Soleau, 2004 from the early Induan of the Western Taurus (Turkey, Crasquin-Soleau et al. 2004), Guangxi, South China (Crasquin-Soleau et al. 2006) and Southern Alps, Italy (Crasquin et al. 2008). Here, the radius of curvature of $A B$ is smaller, the $D B$ is shorter, the $H / L$ ratio is smaller and the thickness is less important in posterior part of the carapace.

NB: in Crasquin-Soleau et al. (2004: 286), there is a printing mistake in the diagnosis of Liuzhinia antalyaensis. It should be as follows:

Diagnosis. - Species of Liuzhinia with long straight dorsal border and maximum of height located in the anterior third.
Suborder METACOPINA

Sylvester-Bradley, 1961

Superfamily HEALDiOIDEA Harlton, 1933

Family HealdiddaE Harlton, 1933

Genus Hungarella Méhes, 1911

TYPE SPECIES. — Hungarella problematica Méhes, 1911.

\section{Hungarella tulongensis Crasquin n. sp. \\ (Fig. 8A-F)}

TYPe MATERial. - Holotype (P6M2662): one complete carapace (Fig. 8A); paratype (P6M2666): one complete carapace (Fig. 8D).

Eтymology. - From the Tulong section, type locality.

MATERIAL EXAMINED. - 230 complete carapaces and 18 isolated valves.

Dimensions. $-\mathrm{L}=380-570 \mu \mathrm{m} ; \mathrm{H}=240-350 \mu \mathrm{m}$. Holotype: $\mathrm{L}=506 \mu \mathrm{m} ; \mathrm{H}=316 \mu \mathrm{m}$. Paratype: $\mathrm{L}=$ $514 \mu \mathrm{m} ; \mathrm{H}=308 \mu \mathrm{m}$.

Type HORizOn. - Unit V, Tulong Formation, Spathian, lower Triassic.

TyPe LOCALITY. - Tulong section, Southern Tibet.

OCCURRENCE. - Tulong section, Southern Tibet. Samples 06Ti20, 06Ti25, 06Ti26, 06Ti28-32 and 06Ti34, units V and VI, Spathian-Anisian, Early-Middle Triassic.

Diagnosis. - A species of Hungarella with dorsal parts straight and carapace laterally compressed at $\mathrm{AB}$.

\section{DESCRIPTION}

$\mathrm{PD}$ and $\mathrm{AD}$ parts long and straight on RV, straight to gently convex on $\mathrm{LV}$; the two parts are at a $140-150^{\circ}$ angle; $A B$ regularly arched with a clear lateral flattening, maximum of convexity located around mid-H; VB regularly convex on both valves; $\mathrm{PB}$ with quite large radius of curvature, maximum of curvature located a little below mid-H; carapace subtriangular with maximum of $\mathrm{H}$ at mid-L or a little in front of; $\mathrm{H} / \mathrm{L}=0.62$;

FIG. 5. - Specimens from Tulong section (Tibet), stored at the Pierre et Marie Curie University Collections (Paris, France): A, Bairdia balatonica Méhes, 1911, right lateral view of a complete carapace (P6M2621); B, Acratia sp. A., right lateral view of a complete carapace (P6M2622); C, Hungarella? sp., right lateral view of right valve (P6M2623); D, E, Bairdiacypris anisica Kozur, 1971; D, right 


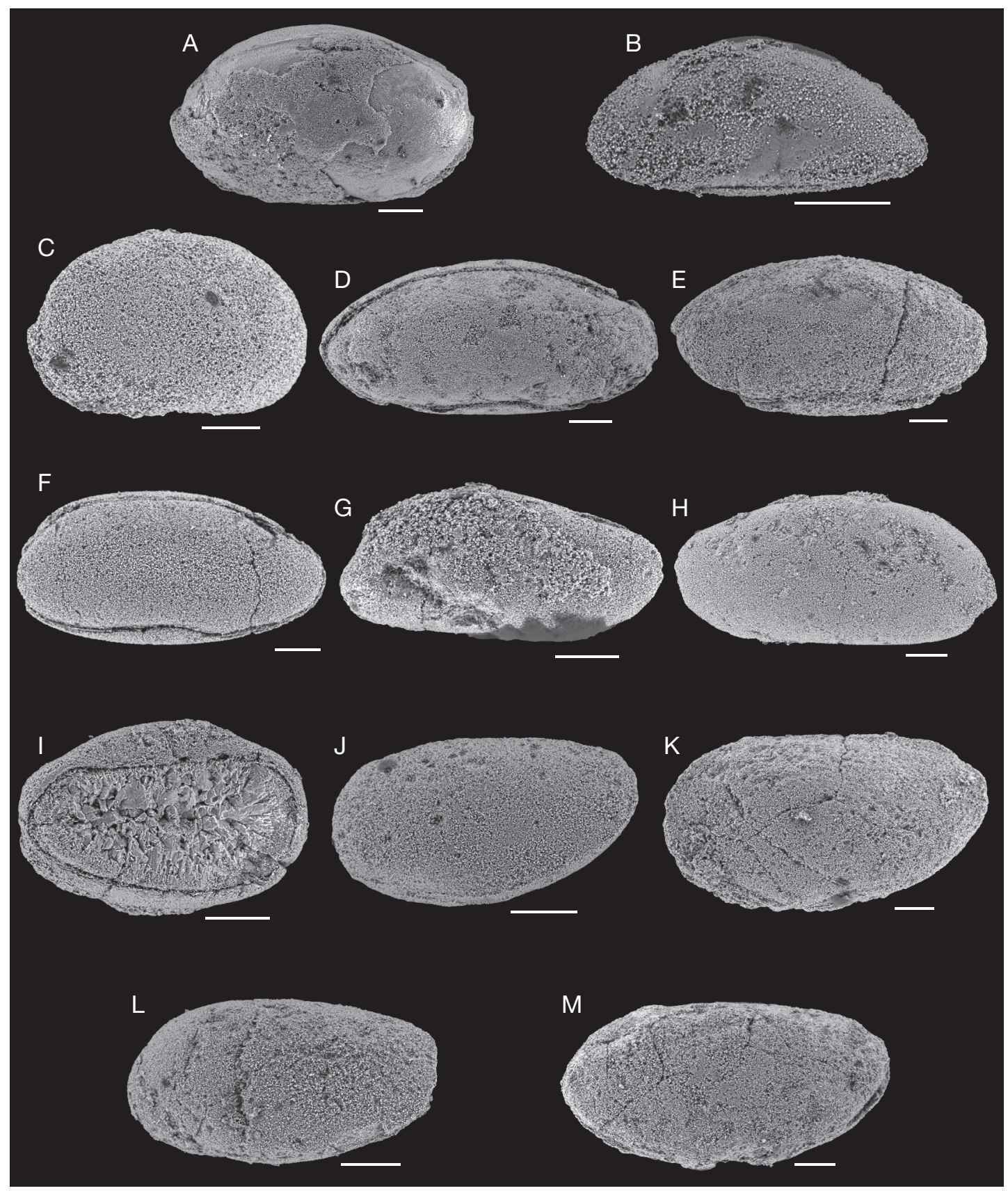

lateral view of a complete carapace (P6M2627); E, right lateral view of a broken carapace (P6M2628); F-H, Bairdiacypris combeae Forel n. sp.; F, holotype (P6M2626), right lateral view of a right valve; G, left lateral view of a complete carapace (P6M2625); H, paratype (P6M2624), left lateral view of left valve; I, Microcheilinella sp. A, right lateral view of left valve (P6M2629); J-M, Triassicindivisia tibetinella Crasquin n. gen., n. sp.; J, holotype (P6M2631), left lateral view of a complete carapace; K, paratype (P6M2632), left lateral view of a complete carapace; L, left lateral view of a complete carapace (P6M2636); M, left lateral view of a complete carapace (P6M2637). Scale bars: $100 \mu \mathrm{m}$. 
LV overlap of LV on RV very weak all around the margins; surface smooth.

\section{REMARKS}

Hungarella tulongensis Crasquin n. sp. differs from the Upper Anisian species "Hungarella" reniformis Méhes, 1911 from Lake Balaton (Hungary; Méhes 1911; Monostori 1995) by H/L smaller and a maximum of convexity of BP located lower. Hungarella elongata (Blake, 1876) from the Late Triassic (Rhaetian) of Great Britain (Anderson 1964) has the same anterior structure but the dorsal outline is less angular and $\mathrm{H} / \mathrm{L}$ is smaller. Hungarella ovata Zheng, 1976 from the Rhaetian of South China (Zheng 1976) is also relatively close to the new species but has a concave VB on RV and a PB with smaller radius of curvature (Hungarella genus needs re-collection and re-description).

Order PALAEOCOPIDA Henningsmoen, 1953 Superfamily indet.

Family indet.

Genus Triassicindivisia Crasquin n. gen.

TYPE SPECIES. - Triassicindivisia tibetinella Crasquin n. sp. (Fig. 5J-M).

ETYMology. - From the similarity with the Devonian genus Indivisia Zaspelova, 1954 (in Egorov 1954).

Type Horizon. - Tulong section, Southern Tibet. Sample 06Ti35, unit VI, Anisian, Middle Triassic.

Distribution. - Middle Smithian to Early Anisian, Tulong section, Southern Tibet.

DiAgnosis. - A new Triassic palaeocopid genus with free margins laterally compressed, without observable sulcus, all surface smooth.

\section{REMARKS}

Triassicindivisia $\mathrm{n}$. gen. is close to the Devonian Indivisia.

\section{Triassicindivisia tibetinella Crasquin n. sp.} (Fig. 5J-M)

TYPE MATERIAL. - Holotype: one complete carapace (P6M2631; Fig. 5J); paratype: one complete carapace (P6M2632; Fig. 5K).

Etymology. - From Tibet, type locality.

Material eXAmined. -8 complete carapaces.

Dimensions. $-\mathrm{L}=460-825 \mu \mathrm{m} ; \mathrm{H}=250-420 \mu \mathrm{m}$. Holotype: $\mathrm{L}=460 \mu \mathrm{m} ; \mathrm{H}=253 \mu \mathrm{m}$. Paratype: $\mathrm{L}=$ $714 \mu \mathrm{m} ; \mathrm{H}=385 \mu \mathrm{m}$.

TyPe Horizon. - Sample 06Ti35, Unit VI, Tulong Formation, Anisian, Middle Triassic.

TyPE LOCALITY. - Tulong section, Southern Tibet.

OCCURRENCE. - Tulong section, Southern Tibet. Samples 06Ti07, 06Ti20, 06Ti31, 06Ti33 and 06Ti35, units III to VI, Smithian-Anisian, Early-Middle Triassic.

Diagnosis. - A species of Triassicindivisia $\mathrm{n}$. gen. with elongated carapace $(\mathrm{H} / \mathrm{L}=0.52), \mathrm{AB}$ and $\mathrm{PB}$ have small radius of curvature.

\section{DESCRIPTION}

Carapace with long straight to gently convex DB; cardinal angles clearly expressed, equivalent and very obtuse $\left(\approx 145\right.$ to $\left.150^{\circ}\right)$; $\mathrm{AB}$ with small radius of curvature, maximum of convexity located at mid-H or a little below; VB regularly curved with maximum of convexity ( $\mathrm{H}$ maximum) in front of mid-L; BP with small radius of curvature, maximum located high at upper $1 / 3$ of $\mathrm{H}$; free margins compressed laterally; RV overlaps LV all along free margins; surface smooth, no primary nor secondary ornamentation; $\mathrm{H} / \mathrm{L}=0.52$.

\section{REMARKS}

This new genus and the type species are reminiscent of Paraparchitoidea by the absence of primary and secondary ornamentation. Internal characters, e.g., muscle scars, were not observed so the superfamily is uncertain for the time being.

FIG. 6. - Specimens from Tulong section (Tibet), stored at the Pierre et Marie Curie University Collections (Paris, France): A, Microcheilinella sp. C, right lateral view of a complete carapace (P6M2635); B, Liuzhinia sp. B, right lateral view of a complete carapace (P6M2634); C-G, Liuzhinia larmae Forel n. sp.; C, holotype (P6M2638), right lateral view of a complete carapace; D, paratype (P6M2639), right lateral view of a complete carapace; E, left lateral view of a complete carapace (P6M2640); $\mathbf{F}$, right lateral view of a complete carapace (P6M2641); G, left lateral view of a complete carapace (P6M2642); H, Acratia cf. symmetrica Hao, 1992, right lateral view 


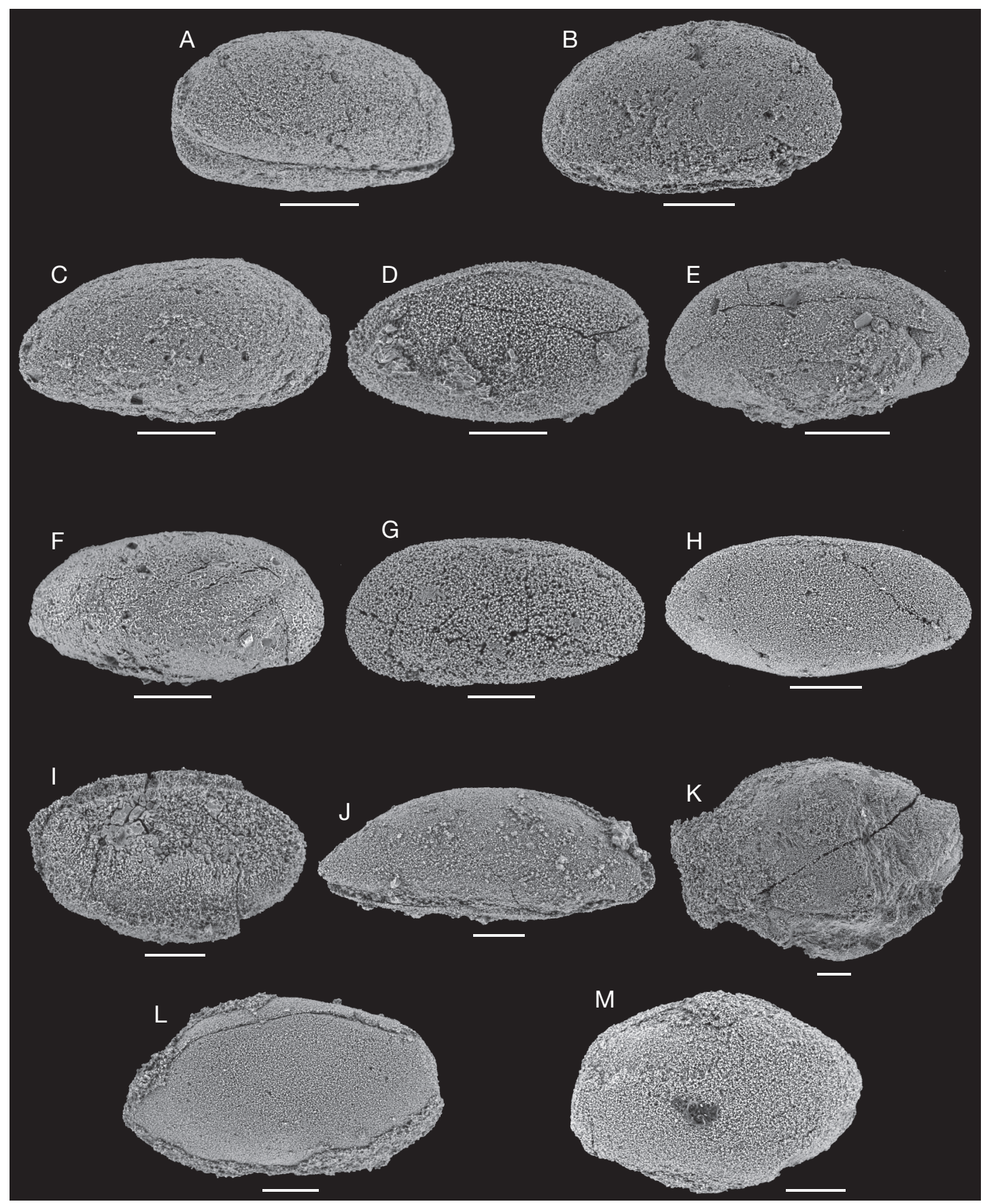

of a complete carapace (P6M2643); I, Microcheilinella sp. B., right lateral view of a broken carapace (P6M2630); J, Acratia goemoeryi Kozur, 1970, right lateral view of a complete carapace (P6M2644); K, Urobairdia? sp., right lateral view of a broken carapace (P6M2645); L, Bairdia cf. cassiana rotundidorsata Monostori, 1995, right lateral view of a complete carapace (P6M2646); M, Bairdia sp. E, right lateral view of a complete carapace (P6M2647). Scale bars: $100 \mu \mathrm{m}$. 


\section{DISCUSSION}

Crasquin et al. (2007) described an early late Griesbachian age fauna from southwestern Tibet (Gyanyima section, Burang area) from which 14 species were recognized. The ostracod fauna presented in this paper is the first described from late Early-Middle Triassic age sediments of Tibet. In Tulong no ostracods were found before the Smithian. The Smithian-Anisian ostracods from Tulong have no species in common with the Griesbachian of Gyanyima. The distribution of the Tulong species is given: Table 1 . Only seven species are recognized in the Smithian. The base of the Spathian is characterized by the first appearance of 15 species (samples 06Ti20 and 21). The discovery of this Lower-Middle Triassic ostracod fauna is very important for understanding the general recovery processes after the upper Permian mass extinction. The ostracod recovery is analysed in another paper (Forel et al. in press).

\section{Acknowledgements}

The authors are grateful to Dr Aymon Baud and Dr Patrice Moix (Lausanne) for their help in the field. We thank the Zurich team (particularly Prof. Hugo Bucher and Dr Thomas Brühwiler) for additional samples from the base of the section and for their help during this work. This paper is part of the IGCP 572 "Restoration of Marine Ecosystems following the Permian-Triassic Mass Extinction: lessons for the present". We are grateful to Prof. Alan Lord (Senckenberg Museum, Frankfurt) and Dr Avraham Honigstein (Ministry of National Infrastructure-Oil and Gas Section, Israel) for their critical reviews and their help in the improvement of this manuscript. We thank Martine Fordant (UPMC) for the processing of samples and the preparation of ostracods and Alexandre Lethiers (UPMC) for the drawings and the figures realization.

\section{REFERENCES}

ANDERSON F. W. 1964. - Rhaetic Ostracoda. Bulletin of Geological Survey of Great Britain 21: 133-174.

Bolz H. 1971. - Die Zlambach-Schichten (alpine Obertrias) unter besonderer Berücksichtigung der Ostrakoden. 1. Ostrakoden der Zlambach-Schichten, besonders Bairdiidae. Senckenbergiana lethaea 52 (2/3): 129-283.

BrÜHWiler T., Goudemand N., Galfetti T., Bucher H., Baud A., Ware D., Hermann E. \& Hochuli P. A. 2009. - Early Triassic sedimentary and isotope records from Tulong (South Tibet). Sedimentary Geology 22 (3-4): 314-332.

Chen D.-Q. \& SHI C.-G. 1982. - [Latest Permian ostracoda from Nantong, Jiangsu and from Miannyang, Hubei]. Bulletin of the Nanjing Institute of Geology and Palaeontology, Academia Sinica 4: 105152 (in Chinese).

Crasquin S., SHEN S. Z., LI W. Z. \& CAO C. Q. 2007. Ostracods from the Lopingian and the Permian-Triassic boundary beds at the Gyanyima section in southwestern Tibet, China. Palaeoworld 16: 222-232.

Crasquin S., Perri M. C., Nicora A. \& De WevER P. 2008. - Ostracods across the Permian-Triassic boundary in Western Tethys: the Bulla parastratotype (Southern Alps, Italy). Rivista Italiana di Paleontologia e Stratigrafia 114 (2): 233-262.

Crasquin-Soleau S., Marcoux J., Angiolini L., Nicora A. \& BERTHO Y. 2004. - New ostracod fauna from Permian-Triassic boundary in Turkey (Taurus, Antalya Nappes). Micropaleontology 50: 281-295.

Crasquin-Soleau S., Vaslet D. \& Le Nindre Y. M. 2005. - Ostracods from Permian-Triassic boundary in Saudi Arabia (Khuff Formation). Palaeontology 48 (4): 853-868.

Crasquin-Soleau S., Galfetti T., Bucher H. \& BRAYARD A. 2006. - Early Triassic ostracods from Guangxi Province, South China. Rivista Italiana di Paleontologia e Stratigrafia 112 (1): 55-75.

Egorov V. G. 1954. - Indivisiinae. A new family of Kloedenellidae from the Frasnian strata of Russian platform. VNIGRI (All Russia Petroleum Research Exploration Institut) 1: 5-21.

Forel M.-B., Crasquin S., BRÜHWILER T., GOUdEMAND N., BUCher H. \& BAUd A. in press. - Ostracod recovery after Permian-Triassic boundary mass-extinction in South Tibet. Palaeogeography, Palaeoclimatology, Palaeoecology.

FIG. 7. - Specimens from Tulong section (Tibet), stored at the Pierre et Marie Curie University Collections (Paris, France): A, Bairdia sp. E, right lateral view of a broken carapace (P6M2651); B, C, Bairdia cf. Bairdia (Urobairdia) sp.1 sensu Monostori, 1995; B, left lateral view of a left valve (P6M2648); C, left lateral view of a left valve (P6M2649); D, Acratia sp. A, right lateral view of a complete carapace (P6M2650); E, Callicythere subovata (Zheng, 1976), right lateral view of a right valve (P6M2652); F, Callicythere cf. mazurensis (Styk, 1972), right lateral view of a right valve (P6M2653); G, Callicythere cf. lysi Crasquin-Soleau, 2004, right lateral view of a 


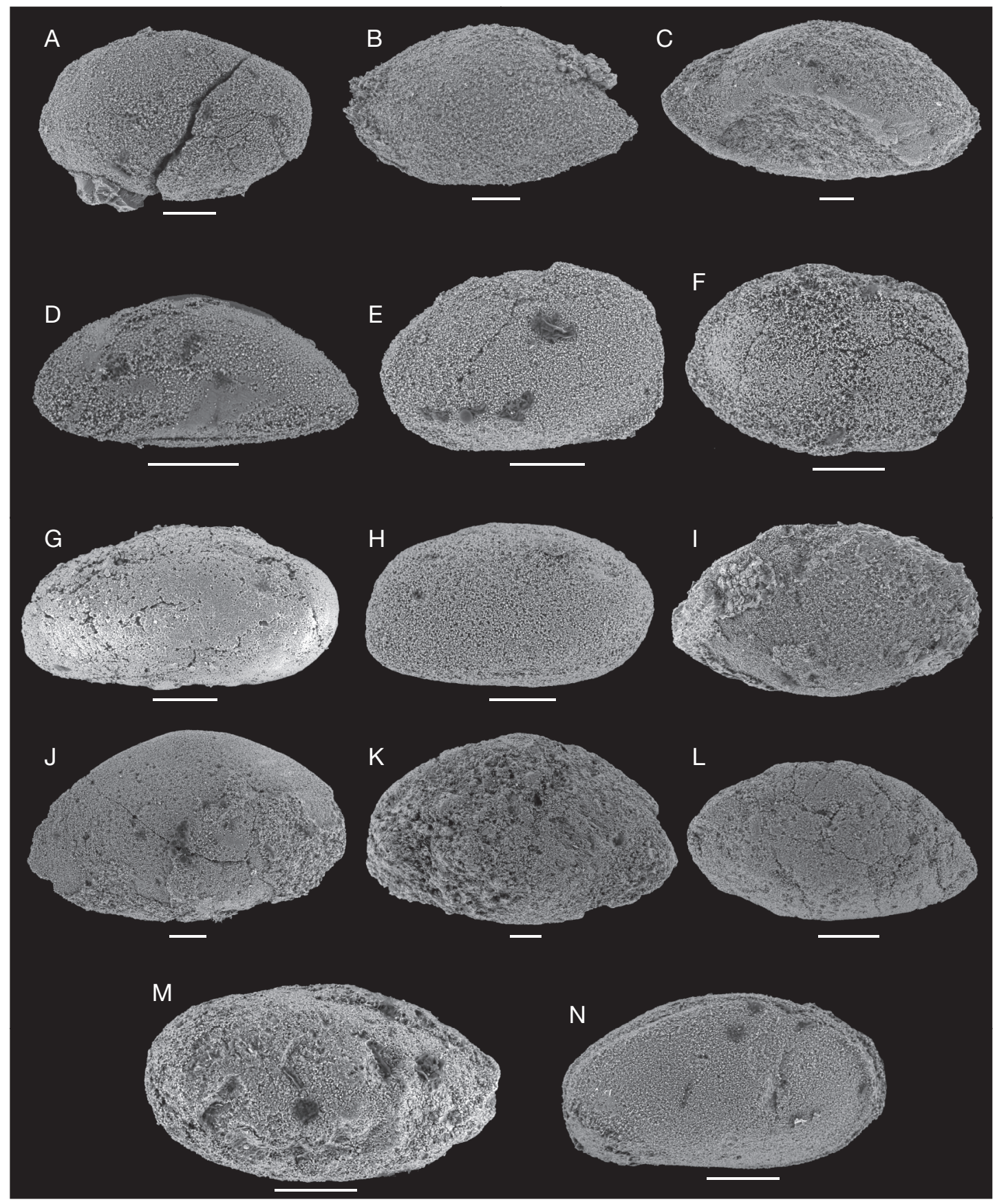

right valve (P6M2651); H, Bythocypris cf. Bythocypris sp. B sensu Bolz, 1971, right lateral view of a right valve (P6M2655); I-L, Citrella ampelsbachensis (Kozur \& Bolz, 1971); I, right lateral view of a complete carapace (P6M2656); J, right lateral view of a complete carapace (P6M2657); K, left lateral view of a complete carapace (P6M2658); L, left lateral view of a complete carapace (P6M2659); M, Cytheropteron? sp. A, left lateral view of a complete carapace (P6M2660); N, Hungarella sp. C, right lateral view of a complete carapace (P6M2669). Scale bars: $100 \mu \mathrm{m}$. 
Garzanti E., Nicora A. \& RetTori R. 1998. - Permo-Triassic boundary and lower to middle Triassic in South Tibet. Journal of Asian Earth Sciences 16: 143-157.

HaO W. C. 1992. — Early Triassic Ostracods from Guizhou. Acta Micropalaeontologica Sinica 9 (1): 37-44.

KozUR H. 1971. — Die Bairdiacea der Trias. Teil I: Skulpturierte Bairdiidae aus Mitteltriassischen Flachwasserablagerungen. Geologisch-Paläontologische Mitteilungen Innsbruck 1 (3): 1-27.

Lethiers F. \& Crasquin-Soleau S. 1988. - Comment extraire des microfossiles à tests calcitiques de roches calcaires dures. Revue de Micropaléontologie 31 (1): 56-61.

MéHes G. 1911. - Über Trias-Ostrakoden aus dem Bakony. Resultate wissenschaftlicher Erforschungen des
Balatonsees 1 (2): 1-38.

MONOSTORI M. 1995. - Environmental significance of the Anisian Ostracoda fauna from the Forras Hill near Felsoors (Balaton Highland, Transdanubia, Hungary). Acta Geologica Hungarica 39 (1): 37-56.

Shen S. Z., Cao C. Q., Henderson C. H., Wang X. D., Shi R. G., Wang Y. \& Wang W. 2006. End-Permian mass extinction pattern in the northern peri-Gondwanan region. Palaeoworld 15: 3-30.

Shi C. G. \& Chen D. Q. 1987. — The Changhsingian ostracodes from Meishan Changxing, Zhejiang. Stratigraphy and Palaeontology of Systemic Boundaries in China; Permian and Triassic Boundary 5: 23-80.

ZHENG S. 1976. - Early Mesozoic ostracods from some localities in South West China. Acta palaeontologica Sinica 15 (1): 77-93. 


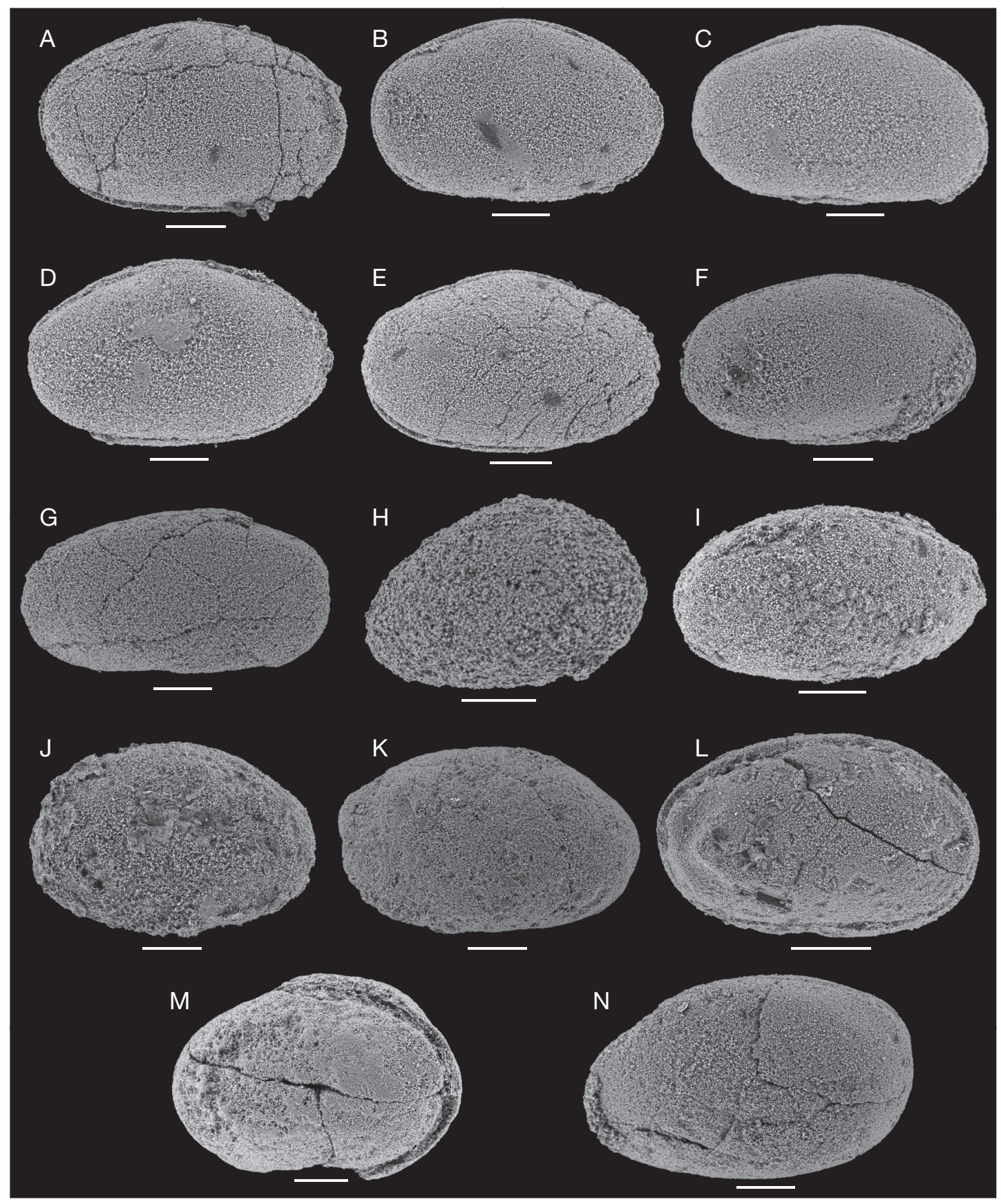

garella sp. B, right lateral view of a complete carapace (P6M2668); H, Liuzhinia guangxiensis Crasquin-Soleau, 2006, right lateral view of a complete carapace (P6M2672); I, Hungarella sp. D, right lateral view of a complete carapace (P6M2670); J, Hungarella sp. E, right lateral view of a complete carapace (P6M2671); K-M, Torohealdia? sp. A; K, left lateral view of a left valve (P6M2675); L, right lateral view of a complete carapace (P6M2673); M, right lateral view of a broken carapace (P6M2674); N, Hungarella sp. A, right lateral view of a complete carapace (P6M2664). Scale bars:100 $\mu \mathrm{m}$. 